\title{
Traditional and Novel Indicators of Climate Change Impacts on European Forest Trees
}

\author{
Filippo Bussotti ${ }^{1, *}$ and Martina Pollastrini ${ }^{1,2}$ \\ 1 Department of Agri-Food Production and Environmental Science (DISPAA), Section of Soil and Plant \\ Science, University of Florence, Piazzale delle Cascine 28, 50144 Firenze, Italy; martpollas@gmail.com \\ 2 Forestry Research Centre, Council for Agricultural Research and Economics (CREA SEL), \\ Viale Santa Margherita 80, 52100 Arezzo, Italy \\ * Correspondence: filippo.bussotti@unifi.it; Tel.: +39-055-275-5851
}

Academic Editor: Timothy A. Martin

Received: 3 February 2017; Accepted: 20 April 2017; Published: 24 April 2017

\begin{abstract}
The concern for the fate of forest ecosystems under climate change demands the development of a prompt and effective system for detecting the impacts of pressure factors, such as rising temperatures, drought conditions, and extreme climatic events. In ongoing European monitoring programs, the health condition of trees is only assessed visually as a matter of course and there is limited evidence that enhanced crown defoliation implies physiological disturbance and reduced tree growth. The progress of the research makes it possible to apply methods developed in experimental conditions in forests for the fast and reliable assessment of impacts and of stress conditions. In this review, we analyze the most promising indicators of tree and forest health (at individual plant and ecosystem levels) for their potential application in forest ecosystems and their ability to support and integrate the traditional visual assessment, provide information on influential factors, and improve the prediction of stand dynamics and forest productivity.
\end{abstract}

Keywords: defoliation; ecosystem services; monitoring programs; tree diversity; tree health; tree mortality

\section{Introduction}

Climate change impacts forest ecosystem health through rises in mean temperature, variations in precipitation regimes, and the enhancement of extreme weather event frequencies. Forest health monitoring activities are actions aimed at detecting conditions and changes in tree species and in forest communities. In Europe, such activities are carried out routinely by means of terrestrial surveys [1] within the International Co-operative Program on Assessment and Monitoring of Air Pollution Effects on Forests (ICP Forests [2]), which is the most comprehensive European program for the large-scale assessment of forest ecosystem health. This program has been active since the 1970s and consists of extensive (more than 100,000 trees growing in 5600 plots across 24 European countries in 2014) and intensive (about 500 plots) monitoring networks. Its main goal is to assess the impacts of atmospheric deposition and air pollution [3]. For these reasons, most efforts are focused on analyzing the chemical compositions of atmospheric depositions and their fate in the soil and foliage. By contrast, the physiological (stress) conditions of trees are only assessed visually, using the indicator of 'crown defoliation', together with attributes such as crown dieback and symptoms displayed on leaves and branches [4].

There are discussions about the physiological significance of defoliation and its suitability for describing the overall crown condition [5]. Some additional analytical parameters can be taken into consideration for the more effective assessment of the crown condition in relation to climatic stress impacts on individual trees and on forest stands. Contemporary advances in research and technology 
make possible the application in forests of methodologies developed in experimental conditions for the fast and reliable assessment of the impact of stress factors on trees.

Forests are believed to provide a large set of ecosystem services in addition to wood and biomass production [6]. Climate change can reduce, or at least modify, the quality and quantity of the ecosystem services that forests provide, thus affecting the economies and cultural identities of local communities. It is, therefore, of primary importance to develop an instrument for policy makers that will anticipate the changes in forest ecosystems' functionalities and their capacity to deliver services.

The emerging issues surrounding the risk of reducing forest capacity to deliver ecosystem services due to climate change effects highlight the need for adopting a holistic view of ecological processes and their interactions with human activities (social-ecological systems, SESs, see [7]). Several frameworks were developed for comprehensive environmental accounting [8,9]. The Driver-Pressure-State-Impact-Response (DPSIR) framework is one of the original tools that the Organization of Economic Cooperation and Development $[10,11]$ and the European Environment Agency [12-14] developed for the adaptive management of SESs. Although it was criticized for the supposed oversimplification of environmental problems, DPSIR is still widely adopted [15].

Driving forces represent economic developments in societies and the overall levels of consumption and production. Such developments may be regarded as primary driving forces. pressures are the effects of driving forces. Examples of pressure indicators are climate extremes, land-use change, ozone deposition and fluxes, and nitrogen deposition. The overall ecological and structural components of the forest define the state. Depending on the changes in the state, there may be positive or negative consequences for ecosystems and society. These consequences are identified and evaluated to describe impacts by means of evaluation indices. Impacts may indicate risks or ongoing processes of change in the state parameters. The perception of the existence of relevant impacts in forests induces decision-makers to develop responses, which prevent, compensate for, or mitigate the impacts.

Pressures induce the passage of the ecosystem from an original state (State 1) into a different condition (State 2). The differences between State 1 and State 2 indicate a change (loss or increase) in ecosystem functions and services. The state of an ecosystem is not merely a passive condition that is subject to pressures and change, but it can actively interact in the modification of impacts on trees.

In this contribution, we analyze the indicators commonly used in the European forest health monitoring program to assess the state and impacts. Based on the current state of the literature, we revise the most promising indicators of tree and ecosystem vitality for their potential application in forests and their capacity to integrate and improve the traditional visual assessment.

\section{Indicators of the State and Impacts}

\subsection{Indicators at Tree-Level}

\subsubsection{Crown Conditions and Growth}

Crown defoliation is the most widely used parameter for the assessment of tree vitality in large-scale terrestrial surveys. It is a visual indicator of the relative amount of foliage in the crown of the assessed tree compared to that in the crown of a reference standard tree. Defoliation is a non-specific parameter integrating intrinsic tree genetic variability, site effects (soil fertility, climatic features, and the structure and composition of forest stands), and external factors, such as abiotic and biotic stresses. Thus, defoliation is not necessarily equivalent to damage and can be considered to be indicative of the equilibrium between the tree and its environment. In this sense, defoliation can be considered to intrinsically indicate the state rather than impact. Year-by-year defoliation changes are fully reversible and are related to fluctuations in climate factors [16].

Impacts are related to sudden increases in defoliation, crown dieback, extensive insect and pathogen attacks, and mortality. The latter is the most relevant parameter of irreversible change in the forest structure. However, [17] demonstrated that defoliation may be a useful parameter for improving models for the prediction of tree mortality in forest inventories. The presence of highly defoliated trees 
may be indicative of the limited capacity of trees to cope with stressful factors and extreme climate events due to their low photosynthetic activity and reduced ability to make starch reserves [18,19].

Further insights can be obtained by means of foliar analysis. Since the greatest difficulty lies in the collection of leaves from tall trees, López et al. [20] proposed a set of additional leaf parameters (morphological and physiological) to optimize the effectiveness of the survey, for measurement once the foliar sample was gathered. Some of these parameters, for instance, leaf area, leaf thickness, and leaf mass per area, are indicative of drought stress (see [20,21]). Among them, special attention should be devoted to carbon isotope composition $\left(\delta^{13} \mathrm{C}\right)$ and chlorophyll $a$ fluorescence $(\mathrm{ChlF})$ analysis. Foliar $\delta^{13} \mathrm{C}$ is a key parameter for exploring carbon sequestration and strategies for trees' efficient use of water under water stress conditions [22]. The increase in foliar $\delta^{13} \mathrm{C}$ indicates a decrease in $\mathrm{CO}_{2}$ concentration in the chloroplast, which might be due to a high assimilation rate and, consequently, a high consumption of $\mathrm{CO}_{2}$ or to low stomatal conductance and, consequently, the restriction of the resupply of $\mathrm{CO}_{2}$ to the photosynthetic apparatus. The availability of water, the effects of water scarcity on stomatal conductance, and high solar radiation that enhances photosynthetic rates, may affect leaf $\delta^{13} \mathrm{C}$ [23]. Chlorophyll $a$ fluorescence is a way of dissipating the excess solar energy that plants and other photosynthetic organisms absorb. Its measurement and parameters yield information on the physiological conditions of plants [24]. The maximum quantum yield of primary photochemistry $\left(\mathrm{F}_{\mathrm{V}} / \mathrm{F}_{\mathrm{M}}\right)$, which is the most commonly used fluorescence parameter, is easily measurable in field conditions with different kinds of instruments [20] and has been probed and determined to be useful for characterizing responses and the adaptation of plants to stress [25]. ChlF analysis, with special reference to prompt fluorescence [26], has been extensively applied in forests [5,27-29], and the relationships between ChlF parameters, crown defoliation, and foliar traits have been explored extensively [30,31]. ChlF fluorescence can also be assessed by means of remote sensing techniques [32]. Future developments may be oriented towards the elaboration of composite indices that describe the overall health status of trees by combining different leaf and crown parameters (morphological, physiological, and health-related parameters, [33]).

Growth integrates the physiological condition of trees in its entirety, and the associated changes are a reliable indicator of Impacts. Defoliation reduces the overall photosynthetic surface, but so-called "compensatory photosynthesis" [34], which occurs due to the better exploitation of solar energy in the inner parts of the crown, may counteract its negative effect on carbon uptake and storage. Some papers report evidence of the reduction of tree ring width in very highly defoliated trees of the species Pinus sylvestris L. [35,36]. Severe stress events (extreme drought and heat waves, parasite attacks) are supposed to induce very high defoliation and lower radial growth $[37,38]$. Severe reduction of tree ring increments may precede tree mortality [39].

Dendroecological analyses make it possible to connect Impacts to past stress conditions [40] to which forest trees were subjected. These analyses are relevant not only for assessing the environmental drivers of the impacts but also for providing evidence of the role of forest stand characteristics in modifying the impacts, for instance, species composition and assemblage [41]. Recovery from severe stress conditions (resilience, [42]) is also information which is relevant for assessing potential risks due to environmental constraints. As observed by [43], in Tsuga heterophylla (Raf.) Sarg. which Neopridion tsugae Middleton subjected to complete defoliation, the time required to completely restore tree growth could be over 5 years, depending on the ages of the trees and the silvicultural treatments undertaken in previous years.

\subsubsection{Biotic Agents and Interactions with Environmental Factors}

Insects and pathogens are considered to potentially play a very strong role in the decline of forests under climate change. The action mechanisms of insect and pathogen attacks may be different. We can identify: (i) an alteration in tree phenology, due to climate change, that influences the population dynamics of insects and pathogens; and (ii) the enhancement of the virulence of the parasites which cause weakness in trees subjected to environmental stress (weakness parasites, sensu [44]). 
Trees subjected to drought stress may experience severe attacks by bark- and wood-boring insects [45], which represent the ultimate cause of tree death. In boreal regions, the susceptibility of Picea abies (L.) Karst. trees to secondary insect attacks is enhanced due to climate events, such as spring temperature backlashes and summer drought, in combination with increases in average air temperatures and the occurrence of extreme climate phenomena [46]. Insect traps [47] are useful tools in monitoring programs for the early detection of the risks of insect attacks on forest stands.

The mechanisms of interaction between drought and fungal diseases are under discussion $[48,49]$. Endophytic agents living in dead parts of living trees cause drought-induced diseases. Water stress often merely reveals their presence by triggering host susceptibility and/or inducing pathogen quiescence. The early detection of these parasites (before they reach the pathogenic stadium) may be crucial for evaluating the vulnerability of forest ecosystems to climate change. Conventional approaches, which are based on the isolation of fungi on culture media, can now be supplemented with highly discriminant DNA-based techniques [50]. Moreover, spore traps [51] may be useful tools for detecting potential risks arising from the diffusion of alien fungal species.

\subsection{Indicators at Stand Level}

Ideally, the ultimate effect of climate change on forests will be the substitution of the current tree species with species better adapted to the new climatic conditions. This change in the species composition of the forest stands would be the result of the concomitant processes of the mortality of the tree species currently present and the regeneration of new species [52-54]. Both processes are already observable in some European regions [55,56]. The best documented cases concern the decline of Pinus sylvestris in Valais (Switzerland) and its replacement with the more xeric species, Quercus pubescens Willd [57], and the replacement of Fagus sylvatica L. with Quercus ilex L. in some mountain areas of the Pyrenees in Spain [58]. Tree mortality and regeneration are therefore "key parameters" for consideration in the study of the fate of forests at the landscape and regional spatial scales. The assessment of tree mortality and regeneration is only partially included in the current planning of the field surveys since they are aimed at assessing the evolution of individual dominant trees, rather than the dynamics of the population.

In some cases, the impact of climate change does not lead to the substitution of the current tree species distribution but may favor so-called "local evolution" [59], i.e., the selection of the best adapted genotypes within the same population. Local evolution is enhanced when the current population has high genetic variability. In this case, we have the regeneration of the same species but with different genetic characteristics. Differences in the genetic structures of the regenerated trees, in comparison to those of the current adult population, may be indicative of ongoing adaptive processes. The capacity of a tree population to survive under climate change is connected not only to its genetic variability but also to each tree's individual ability to modulate the phenotype in order to resist worsened environmental conditions. This ability is called "phenotypic plasticity", and it is genetically controlled [60]. Epigenetic factors play an important role in phenotypic plasticity; they induce changes in gene expression and phenotype without changing a DNA sequence. Epigenetic changes happen much more rapidly than DNA sequence-based changes [61], and these mechanisms can be maintained for some time after stress factors have ceased to exist (memory effect, see [62]). Epigenetic responses may be at the root of acquired resistance.

The dynamism of forest vegetation can be monitored by measuring the leaf area index, LAI [63]. This parameter expresses the overall foliar surface per ground surface unit $\left(\mathrm{m}^{2} \mathrm{~m}^{-2}\right)$, and it is connected to important ecosystem-regulating services such as the cooling of the climate (through transpiration), air pollution interception, and element turnover. The assessment of LAI is fast and reliable using indirect methods [64], and it is already applied in monitoring programs. However, its informative potential can be increased by estimating drought stress-related parameters at the stand level (transpiration and stomatal conductance) by means of measuring the sap flow in the tree stem [65]. 
Increasingly dry conditions will also affect processes at the soil level, for instance, the content of carbon and organic matter (currently assessed in large-scale surveys [66]), the litter decomposition rate [67], and soil respiration [68]. The litter decomposition rate is a crucial ecosystem function for elemental cycling and depends on microorganism (bacteria and fungi) activity, which is more intense in moist conditions. Soil respiration is indicative of the overall microbial and fine root loads. Litter production (estimated by means of LAI), combined with the decomposition rate and soil respiration, is powerful, enabling the balance of organic matter in the soil and, consequently, the effectiveness of forest ecosystems in the mitigation of climate change.

\subsection{Linking Terrestrial and Aerial Surveys}

Some authors have investigated the feasibility of assessing defoliation by means of remote sensing. For instance, [69] used tree-level airborne laser scanned data; [70] applied color-infrared ortophoto maps. Although the outputs showed promising results, these techniques are not widely applied in the ongoing progress of the surveys. However, the most advanced studies for detecting stress conditions in forests consider the analysis of passive chlorophyll fluorescence [32,71]. The European Space Agency (ESA) launched a European-wide program, based on the Fluorescence Explorer (FLEX) mission, for the assessment of the physiological conditions of vegetation [72]. Through the analysis of the optical properties of leaves and canopies, remote sensing can estimate several functional attributes such as the biochemical, structural, and physiological traits of leaves and canopies, including nitrogen concentration, photosynthetic pigment and water content, leaf mass per area, carbon isotope composition, leaf area index, and biomass [31,73-75]. The overall analysis of spectral traits is fundamental for aerial forest health surveys [76,77]. Remote sensing needs to be validated with field-collected data, and making the connections between terrestrial and aerial surveys is a very challenging task [78] since the two approaches use different criteria that are hardly connected. Chlorophyll fluorescence may provide a link between ground and airborne observation [71] although the different approaches (active vs. passive fluorescence, [79]) are not easily comparable.

\section{Discussion}

The ecological processes that climate change triggers can lead the forest ecosystem to a different state (State 1 and State 2, see Figure 1) in a dynamic equilibrium with the new climatic conditions (the new conditions are, in turn, subjected to rapid change, and the equilibrium point shifts continuously). Changes in forest structure and functioning may be very variable: In Southern Europe and in some regions of Central Europe, where the provisional models suggest substantial decreases in precipitation [80], the forests will likely have lower densities and support less biomass, and they may comprise drought-resistant species with lower growth rates. In general, we can suppose them to offer lower levels of ecosystem services although some features may be enhanced (e.g., the biodiversity of plant species) [81].

By contrast, in Central Europe, trees can benefit from higher mean temperatures and extended growing seasons, showing increased growth rates [82,83]. In Northern Europe, the areas suitable for forests are supposed to extend northwards [84], but the interactions between trees and the bark beetle due to higher winter temperatures [85] and the lack of a genotype suited to the northernmost conditions (with special reference to the length of the day) [86] may limit the potential benefits.

The role of forest monitoring is to detect early signals of such changes so that managers and policy makers can elaborate responses for the adaptation of the forests to the new climate and for that of society to the new forests. Actions that can be taken include silvicultural measures and new bioeconomic strategies (new products and services from new forests). For these reasons, it is necessary to have a comprehensive monitoring system, including a set of reliable and informative indicators in combination with those traditionally applied in the current programs. 


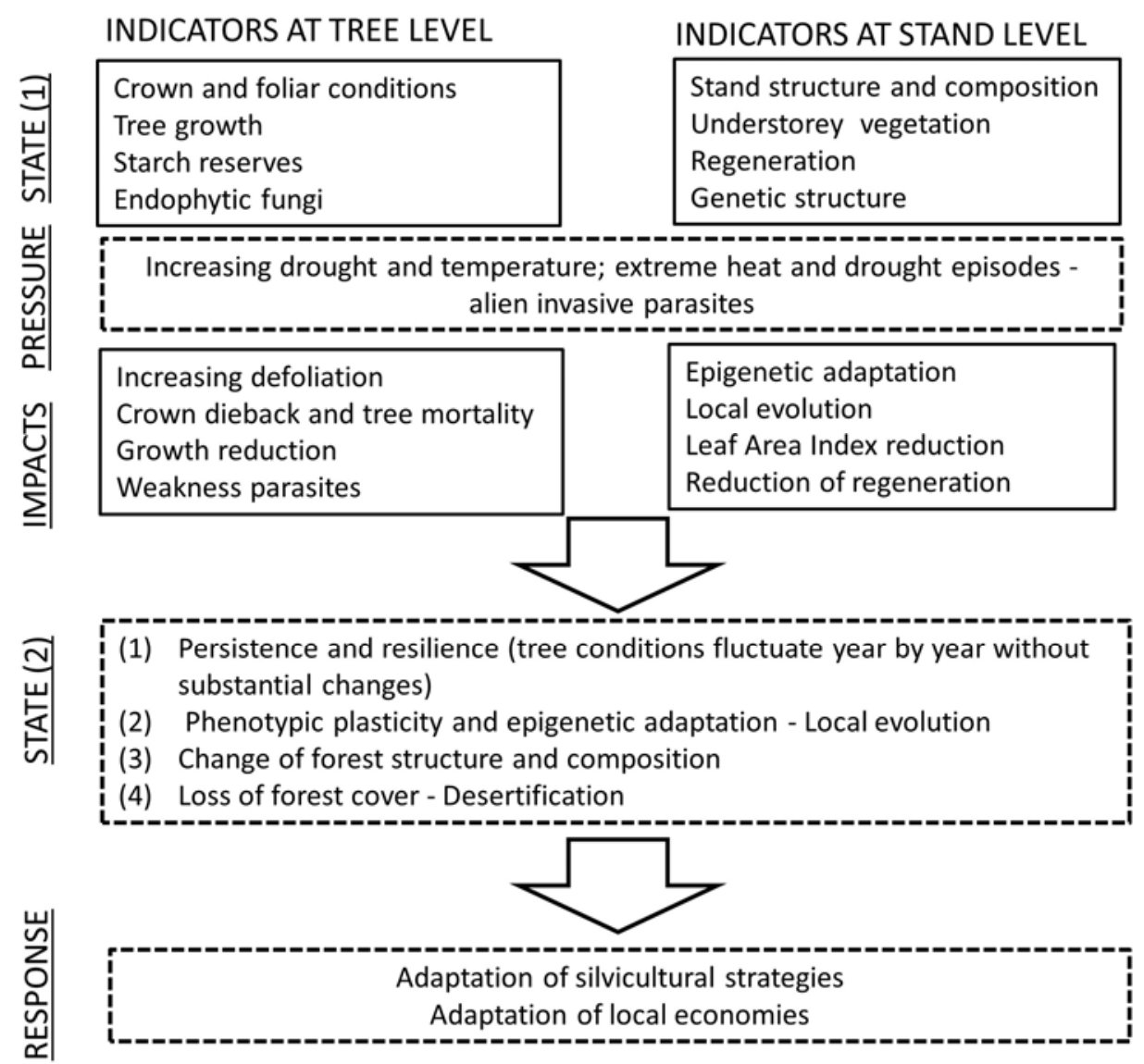

Figure 1. Indicators at tree- and stand-level to detect states of ecosystems and their responses to pressure and impacts of environmental factors.

The sampling and assessment of adult trees in forest conditions poses specific problems, such as the standardization of sampling procedures, the variability of the parameters considered within the plant and the stand, and the role of ecological and structural features in modifying the Impacts. These methodological issues have been addressed in $[5,27,29,87]$ for the assessment of chlorophyll $a$ fluorescence properties. Thanks to the results of these studies, we can now select the most robust and reliable parameters to assess the physiological vitality of trees and to interpret them in relation to the functional traits and ecological behavior of a tree species.

Most of the parameters proposed in this paper (summarized in Table 1) are not new since they were assessed individually in specific studies. What is new is the perspective identified for application in multi-parameter surveys carried out on a large spatial scale to obtain the effective phenotyping of the overall tree condition and understand the relations between tree condition and the ecological and structural features of the forest stand. An initial attempt to integrate different data in a holistic vision was carried out within the exploratory platform of the FunDivEUROPE project [88], which highlighted the importance of observatory activities and field investigations for supporting large-scale surveys.

The most promising and challenging perspectives for increasing the effectiveness of large-scale surveys rely on the possibility of connecting ecological and phenotypic data with studies at the molecular level. The study of genetic structure and the responses at the molecular level in relation to stress factors may play a strategic role in determining the true ecological significance of the indicators of tree stress conditions that this paper considers. Epigenetic responses, on the other hand, are involved in the physiological adjustments of trees, leading to acclimation and, thus, protecting the plants from further stressful events. 
Table 1. Traditional and proposed sets of indicators for the assessment of changes in forest stands and trees under climate change, in extensive surveys.

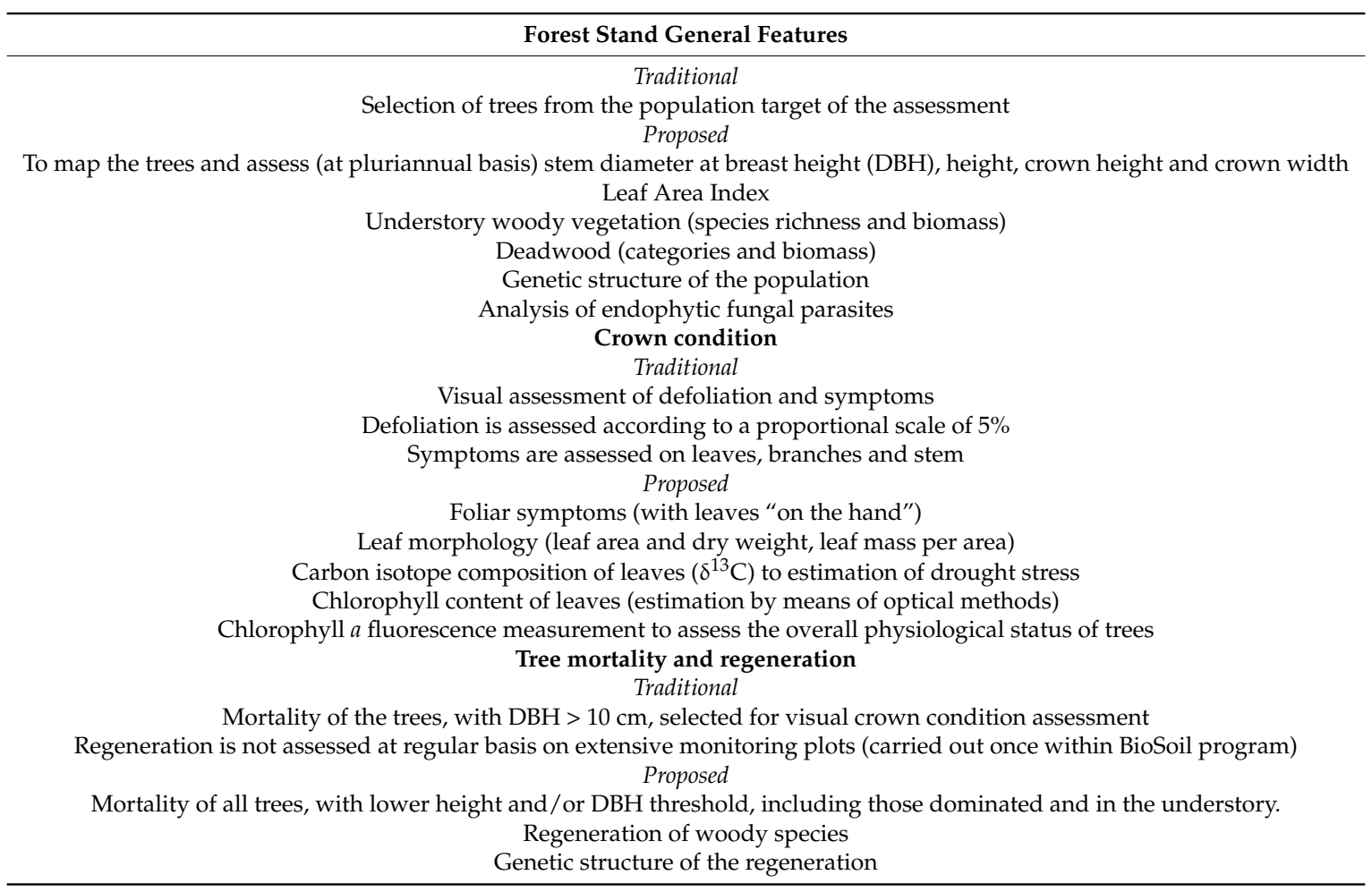

\section{Conclusions}

The future large-scale distribution of tree species across Europe is currently predicted using different kinds of models, whose accuracy and precision are increasing (they range from climatic and bioclimatic envelope models to process-based dynamic vegetation models; for review see $[89,90])$. Locally, however, the ability of plants and ecosystems to cope with stressful conditions can modify the effect of climate change on forest communities. The factors involved in enhancing resistance/resilience are connected to the structure and composition of tree species assemblage, genetic variability within the population, and the epigenetic responses of trees, which are at the root of their phenotypic plasticity. On the other hand, there are environmental factors that can exacerbate climate change effects, leading to the quick decline of forest stands. Among them, the altered relationships between host trees and weakness parasites are of special interest.

The analysis of worldwide meteorological datasets, combined with other ecological factors, such as soil conditions, can help to identify the most vulnerable forest sites (hotspots). The overall evaluation of the risks (or resilience/adaptation) should also consider information from other datasets concerning forest structure and composition (National Forest Inventories) and genetic features (EUFORGEN, [91]). The impacts assessed at the ground level should contribute to the validation of airborne observations (i.e., in FLEX-based programs). The ad hoc promotion of cooperation and studies to enhance the comparability of and interactions between field and remote-sensing surveys, is of primary importance.

A "new generation" of monitoring systems that integrates the measurement of the Impacts with the analysis of the ecological, structural, and genetic features of a population, combining data from different existing datasets and promoting the application of novel indicators, can help to produce useful knowledge for the prediction of the fate of forests and for the adoption of effective management strategies. The implementation of an updated forest monitoring system in Europe, explicitly aimed at assessing climate change effects on vegetation, may contribute to the promotion of similar initiatives in different geographical regions of the world where forest health surveys are being carried out, for example, in Eastern Asia and North America [1]. 
Finally, it is necessary to establish close connections among monitoring, observational, and experimental activities in forests to produce evidence of the cause-effect relationships among pressures, states, and impacts.

Acknowledgments: The data and comments in this paper are supported by the observations, elaborations and experiments carried out within the 7 FP FunDivEUROPE (Functional Significance of Forest Diversity in Europe) Project number 265171; LIFE13 ENV/IT/000813 SMART4Action "Sustainable monitoring and reporting to inform forest- and environmental awareness and protection"; Forest Focus, BioSoil and FutMon programs.

Conflicts of Interest: The authors declare no conflict of interest.

\section{References}

1. Ferretti, M.; Fisher, R. Forest Monitoring, Methods for Terrestrial Investigations in Europe with an Overview of North America and Asia; Development in Environmental Science, 12 Series; Krupa, S., Ed.; Elsevier: Amsterdam, The Netherlands, 2013; p. 507.

2. ICP-Forests. 30 Years of Monitoring the Effects of Long Range Transboudary Air Pollution on Forests in Europe and beyond. Available online: http:/ /icp-forests.net/ (accessed on 10 March 2017).

3. De Vries, W.; Dobbertin, M.H.; Solberg, S.; van Dobben, H.F.; Schaub, M. Impacts of acid deposition ozone exposure and weather conditions in Europe: An overview. Plant Soil 2014, 380, 1-45. [CrossRef]

4. Eichhorn, J.; Roskams, P.; Potocic, N.; Timermann, V.; Ferretti, M.; Mues, V.; Szepesi, A.; Durrant, D.; Seletkovic, I.; Schröck, H.W.; et al. Part IV: Visual Assessment of Crown Condition and Damaging Agents. In Manual on Methods and Criteria for Harmonized Sampling, Assessment, Monitoring and Analysis of the Effects of Air Pollution on Forests; UNECE ICP Forests Programme Coordinating Centre, Thünen Institute of Forest Ecosystems: Eberswalde, Germany, 2016; p. 54.

5. Pollastrini, M.; Feducci, M.; Bonal, D.; Fotelli, M.; Gessler, A.; Gossiord, C.; Guyot, V.; Jactel, H.; Nguyen, D.; Radoglou, K.; et al. Physiological significance of forest tree defoliation: Results from a survey in a mixed forest in Tuscany (central Italy). For. Ecol. Manag. 2016, 361, 170-178. [CrossRef]

6. World Health Organization. Millennium Ecosystem Assessment. Ecosystems and Human Well-Being: Synthesis; The Millennium Ecosystem Assessment Series; Island Press: Washington, DC, USA, 2005; pp. 1-137.

7. Anderies, J.M.; Janssen, M.A.; Ostrom, E. A Framework to Analyze the Robustness of Social-ecological Systems from an Institutional Perspective. Ecol. Soc. 2004, 9, 18. [CrossRef]

8. De Jonge, V.N.; Pinto, R.; Turner, R.K. Integrating ecological, economic and social aspects to generate useful management information under the EU directives' 'ecosystem approach'. Ocean Coast. Manag. 2012, 68, 169-188. [CrossRef]

9. Gari, S.R.; Newton, A.; Icely, J.D. A review of the application and evolution of the DPSIR framework with an emphasis on coastal social-ecological systems. Ocean Coast Manag. 2015, 103, 63-77. [CrossRef]

10. OECD. OECD Core Set of Indicators for Environmental Performance Reviews; Organization for Economic Cooperation and Development: Paris, France, 1993; p. 93.

11. OECD. OECD Key Environmental Indicators; Organization for Economic Cooperation and Development, Environment Directorate: Paris, France, 2004; p. 38.

12. European Environmental Agency. Europe's Environment: The Dobris Assessment; European Environmental Agency: Copenhagen, Denmark, 1995; p. 8.

13. European Environmental Agency. Environmental Indicators: Typology and Overview; European Environment Agency: Copenhagen, Denmark, 1999; p. 19.

14. European Environmental Agency. Environmental Indicators: Typology and Use in Reporting; European Environment Agency: Copenhagen, Denmark, 2003; p. 20.

15. Patrício, J.; Elliott, M.; Mazik, K.; Papadopoulou, K.N.; Smith, C. DPSIR-Two Decades of Trying to Develop a Unifying Framework for Marine Environmental Management? Front. Mar. Sci. 2016, 3, 177. [CrossRef]

16. Ferretti, M.; Nicolas, M.; Bacaro, G.; Brunialti, G.; Calderisi, M.; Croisé, L.; Frati, L.; Lanier, M.; Maccherini, S.; Santi, E.; et al. Plot-scale modeling to detect size, extent, and correlates of changes in tree defoliation in French high forests. For. Ecol. Manag. 2014, 311, 56-69. [CrossRef]

17. Dobbertin, M.; Brang, P. Crown defoliation improves tree mortality models. For. Ecol. Manag. 2001, 141, 271-284. [CrossRef] 
18. Marçais, B.; Bréda, N. Role of an opportunistic pathogen in the decline of stressed oak trees. J. Ecol. 2006, 94, 1214-1223. [CrossRef]

19. López, B.C.; Gracia, C.A.; Sabaté, S.; Keenan, T. Assessing the resilience of Mediterranean holm oaks to disturbances using selective thinning. Acta Oecol. 2009, 35, 849-854. [CrossRef]

20. Bussotti, F.; Pollastrini, M. Evaluation of leaf features in forest trees: Methods, techniques, obtainable information and limits. Ecol. Ind. 2015, 52, 219-230. [CrossRef]

21. Bussotti, F. Functional leaf traits, plant communities and acclimation processes in relation to oxidative stress in trees: A critical overview. Glob. Chang. Biol. 2008, 14, 2727-2739. [CrossRef]

22. Farquhar, G.D.; O'Leary, M.H.; Berry, J.A. On the relationship between carbon isotope discrimination and the intercellular carbon dioxide concentration in leaves. Aust. J. Plant Physiol. 1982, 9, 121-137. [CrossRef]

23. Gessler, A.; Schrempp, S.; Matzarakis, A.; Mayer, H.; Rennenberg, H.; Adams, M. Radiation modifies the effect of water availability on the carbon isotope composition of beech (Fagus sylvatica). New Phytol. 2001, 150, 653-664. [CrossRef]

24. Papageorgiou, G.C.; Govindjee. Chlorophyll Fluorescence: A Signature of Photosynthesis; Advances in Photosynthesis and Respiration Series; Springer: Dordrecht, The Netherlands, 2004; p. 820.

25. Kalaji, H.M.; Jajoo, A.; Oukarroum, A.; Brestic, M.; Zivcak, M.; Samborska, I.A.; Cetner, M.D.; Łukasik, I.; Goltsev, V.; Ladle, R.J. Chlorophyll a fluorescence as a tool to monitor physiological status of plants under abiotic stress conditions. Acta Physiol. Plant 2016, 38. [CrossRef]

26. Strasser, R.J.; Tsimilli-Michael, M.; Srivastava, A. Analysis of the fluorescence transient. In Chlorophyll Fluorescence: A Signature of Photosynthesis; Advances in Photosynthesis and Respiration Series; Papageorgiou, G.C., Govindjee, Eds.; Springer: Dordrecht, The Netherlands, 2004; pp. 321-362.

27. Pollastrini, M.; Holland, V.; Brüggemann, W.; Bruelheide, H.; Dănilă, I.C.; Jaroszewicz, B.; Valladares, F.; Bussotti, F. Taxonomic and ecological relevance of the chlorophyll $a$ fluorescence signature of tree species in mixed European forests. New Phytol. 2016, 212, 51-65. [CrossRef] [PubMed]

28. Pollastrini, M.; Holland, V.; Brüggemann, W.; Bussotti, F. Chlorophyll a fluorescence analysis in forests. Ann. Bot. 2016, 6, 57-71.

29. Pollastrini, M.; Garcia Nogales, A.; Benavides, R.; Bonal, D.; Finér, L.; Fotelli, M.; Gessler, A.; Grossiord, C.; Radoglou, K.; Strasser, R.J.; et al. Tree diversity affects chlorophyll $a$ fluorescence and other leaf traits of tree species in a boreal forest. Tree Physiol. 2017, 32, 199-208. [CrossRef] [PubMed]

30. Gottardini, E.; Cristofolini, F.; Cristofori, A.; Camin, F.; Calderisi, M.; Ferretti, M. Consistent response of crown transparency, shoot growth and leaf traits on Norway spruce (Picea abies (L.) H. Karst.) trees along an elevation gradient in northern Italy. Ecol. Ind. 2016, 60, 1041-1044. [CrossRef]

31. Damm, A.; Elbers, J.; Erler, E.; Gioli, B.; Hamdi, K.; Hutjes, R.; Kosvancova, M.; Meroni, M.; Miglietta, F.; Moersch, A.; et al. Remote sensing of sun induced fluorescence to improve modeling of diurnal courses of gross primary production (GPP). Glob. Chang. Biol. 2010, 16, 171-186. [CrossRef]

32. Meroni, M.; Rossini, M.; Guanter, L.; Alonso, L.; Rascher, U.; Colombo, R.; Moreno, J. Remote sensing of solar induced chlorophyll fluorescence: Review of methods and applications. Remote Sens. Environ. 2009, 113, 2037-2051. [CrossRef]

33. Pollastrini, M.; Maggino, F.; Bonal, D.; Brueggemann, W.; Fotelli, M.; Gessler, A.; Grossiord, C.; Holland, V.; Guyot, V.; Jactel, H.; et al. Towards a new multidimensional indicator of tree crown status. In Sustaining Ecosystem Services in Forest Landscapes, Book of Abstract, Proceeding of IUFRO Landscape Ecology Conference Sustaining Ecosystem Services in Forest Landscapes-Concepts, research, and applications, Tartu, Estonia, 23-30 August 2015; IUFROLE WG Conference: Tartu, Estonia, 2015; p. 126.

34. Anten, N.P.R.; Ackerly, D.D. Canopy-level photosynthetic compensation after defoliation in a tropical understorey palm. Funct. Ecol. 2001, 15, 252-262.

35. Augustaitis, A.; Bytnerowicz, A. Contribution of ambient ozone to Scots pine defoliation and reduced growth in the Central European forests: A Lithuanian case study. Environ. Pollut. 2008, 155, 436-445. [CrossRef] [PubMed]

36. Castagneri, D.; Bottero, A.; Motta, R.; Vacchiano, G. Repeated spring precipitation shortage alters individual growth patterns in Scots pine forests in the Western Alps. Trees 2015, 29, 1699-1712. [CrossRef]

37. Carnicer, J.; Coll, M.; Ninyerola, M.; Pons, X.; Sánchez, G.; Peñuelas, J. Widespread crown condition decline, food web disruption, and amplified tree mortality with increased climate change-type drought. Proc. Natl. Acad. Sci. USA 2011, 108, 1474-1478. [CrossRef] [PubMed] 
38. Morin, R.S.; Randolph, K.D.C.; Steinman, J. Mortality rates associated with crown health for eastern forest tree species. Environ. Monit. Assess. 2015, 187, 87. [CrossRef] [PubMed]

39. Juknys, R.; Vencloviene, J.; Jurkonis, N.; Bartkevicius, E.; Sepetiene, J. Relation between individual tree mortality and tree characteristics in a polluted and non-polluted environment. Environ. Monit. Assess. 2006, 121, 519-542. [CrossRef] [PubMed]

40. Grossiord, C.; Granier, A.; Ratcliffe, S.; Bouriaud, O.; Bruelheide, H.; Chećko, E.; Forrester, D.I.; Dawud, S.M.; Finér, L.; Pollastrini, M.; et al. Tree diversity does not always improve resistance of forest ecosystems to drought. Proc. Natl. Acad. Sci. USA 2014, 41, 14812-14815. [CrossRef] [PubMed]

41. Jucker, T.; Bouriaud, O.; Avacaritei, D.; Coomes, D.A. Stabilizing effects of diversity on aboveground wood production in forest ecosystems: Linking patterns and processes. Ecol. Lett. 2014, 17, 1560-1569. [CrossRef] [PubMed]

42. Lloret, F.; Keeling, E.G.; Sala, A. Components of tree resilience: Effects of successive low-growth episodes in old ponderosa pine forests. Oikos 2011, 120, 1909-1920. [CrossRef]

43. Nealis, V.G.; Turnquist, R. Impact and recovery of western hemlock following disturbance following by forestry and insect defoliation. For. Ecol. Manag. 2010, 260, 699-706. [CrossRef]

44. Vannini, A.; Scarascia Mugnozza, G. Water stress: A predisposing factor in the pathogenesis of Hypoxylon mediterraneum on Quercus cerris. For. Pathol. 1991, 21, 193-201. [CrossRef]

45. Wermelinger, B.; Rigling, A.; Schneider Mathis, D.; Dobbertin, M. Assessing the role of bark- and wood-boring insects in the decline of Scots pine (Pinus sylvestris) in the Swiss Rhone valley. Ecol. Entom. 2007, 33, 239-249. [CrossRef]

46. Schlyter, P.; Stjernquist, I.; Bärring, L.; Jönsson, A.M.; Nilsson, C. Assessment of the impacts of climate change and weather extremes on boreal forests in northern Europe, focusing on Norway spruce. Clim. Res. 2006, 31, 75-84. [CrossRef]

47. Bashford, R. The development of static trapping systems to monitor for wood-boring insects in forestry plantations. Aust. For. 2008, 71, 236-241. [CrossRef]

48. Desprez-Loustau, M.L.; Marçais, B.; Nagelsein, L.M.; Piou, D.; Vannini, A. Interactive effects of drought and pathogens in forest trees. Ann. Sci. For. 2006, 63, 597-612. [CrossRef]

49. La Porta, N.; Capretti, P.; Thomsen, I.M.; Kasanen, R.; Hietala, A.M.; Von Weissenberg, K. Forest pathogens with higher damage potential due to climate change in Europe. Can. J. Plant Pathol. 2008, 30, 177-195. [CrossRef]

50. Moricca, S.; Ragazzi, A. Fungal Endophytes in Mediterranean Oak Forests: A Lesson from Discula quercina. Phytopathology 2008, 98, 380-386. [CrossRef] [PubMed]

51. West, J.S.; Kimber, R.B.E. Innovations in air sampling to detect plant pathogens. Ann. Appl. Biol. 2015, 166, 4-17. [CrossRef] [PubMed]

52. Allen, C.D.; Macalady, A.K.; Chenchouni, H.; Bachelet, D.; McDowell, N.; Vennetier, M.; Kitzberger, T.; Rigling, A.; Breshears, D.D.; Hogg, E.H.; et al. A global overview of drought and heat-induced tree mortality reveals emerging climate change risks for forests. For. Ecol. Manag. 2010, 259, 660-684. [CrossRef]

53. Anderegg, W.R.L.; Kane, J.M.; Anderegg, L.D.L. Consequences of widespread tree mortality triggered by drought and temperature stress. Nat. Clim. Chang. 2012, 3, 30-36. [CrossRef]

54. Millar, C.I.; Stephenson, N.L. Temperate forest health in an era of emerging megadisturbance. Science 2015, 349, 823-826. [CrossRef] [PubMed]

55. Bussotti, F.; Ferrini, F.; Pollastrini, M.; Fini, A. The challenge of Mediterranean sclerophyllous vegetation under climate change: From acclimation to adaptation. Environ. Exp. Bot. 2014, 103, 80-98. [CrossRef]

56. Bussotti, F.; Pollastrini, M.; Holland, V.; Brüggemann, W. Functional traits and adaptive capacity of European forests to climate change. Environ. Exp. Bot. 2015, 111, 91-113. [CrossRef]

57. Weber, P.; Bugmann, H.; Rigling, A. Radial growth responses to drought of Pinus sylvestris and Quercus pubescens in an inner-Alpine dry valley. J. Veg. Sci. 2007, 18, 777-792. [CrossRef]

58. Peñuelas, J.; Ogaya, R.; Boada, M.; Jump, A.S. Migration, invasion and decline: Changes in recruitment and forest structure in a warming-linked shift of European beech forest in Catalonia (NE Spain). Ecography 2007, 30, 829-837. [CrossRef]

59. Aitken, S.N.; Yeaman, S.; Holliday, J.A.; Wang, T.; Curtis-McLane, S. Adaptation, migration or extirpation: Climate change outcomes for tree populations. Evol. Appl. 2008, 1, 95-111. [CrossRef] [PubMed] 
60. Nicotra, A.B.; Atkin, O.K.; Bonser, S.P.; Davidson, A.M.; Finnegan, E.J.; Mathesius, U.; Poot, P.; Purugganan, M.D.; Richards, C.L.; Valladares, F.; et al. Plant phenotypic plasticity in a changing climate. Trends Plant Sci. 2010, 15, 684-692. [CrossRef] [PubMed]

61. Bossdorf, O.; Richards, C.L.; Pigliucci, R. Epigenetics for ecologists. Ecol. Lett. 2008, 11, 106-115. [CrossRef] [PubMed]

62. Crisp, P.A.; Ganguly, D.; Eichten, S.R.; Borevitz, J.O.; Pogson, B.J. Reconsidering plant memory: Intersections between stress recovery, RNA turnover, and epigenetics. Sci. Adv. 2016, 2, e1501340. [CrossRef] [PubMed]

63. Manetti, M.C.; Pelleri, F.; Becagli, C.; Conedera, M.; Schleppi, P.; Zingg, A. Growth Dynamics and Leaf Area Index in Chestnut Coppices Subjected to a New Silvicultural Approach: Single-Tree-Oriented Management. Acta Hort. 2014, 1043, 121-128. [CrossRef]

64. Bréda, N.J.J. Ground-based measurements of leaf area index: A review of methods, instruments and current controversies. J. Exp. Bot. 2003, 54, 2403-2417. [CrossRef] [PubMed]

65. Granier, A. Evaluation of transpiration in a Douglas-fir stand by means of sap flow measurements. Tree Physiol. 1987, 3, 309-320. [CrossRef] [PubMed]

66. Andersson, K.; Evans, T.P.; Richards, K.R.; Kenneth, R. National forest carbon inventories: Policy needs and assessment capacity. Clim. Chang. 2009, 93, 9-101. [CrossRef]

67. Robertson, G.P.; Paul, E.A. Decomposition and soil organic matter dynamics. In Methods of Ecosystem Science; Sala, O.E., Jackson, R.B., Mooney, H.A., Howarth, R.W., Eds.; Springer-Verlag: New York, NY, USA, 1999; pp. 104-116.

68. Rochette, P.; Ellert, B.; Gregorich, E.G.; Desjardins, R.L.; Pattey, E.; Lessard, R.; Johnson, B.G. Description of a dynamic closed chamber for measuring soil respiration and its comparison with other techniques. Can. J. Soil Sci. 1997, 77, 195-203. [CrossRef]

69. Kantola, T.; Vastaranta, M.; Yu, X.; Lyytikainen-Saarenmaa, P.; Holopainen, M.; Talvitie, M.; Kaasalainen, S.; Solberg, S.; Hyyppa, J. Classification of Defoliated Trees Using Tree-Level Airborne Laser Scanning Data Combined with Aerial Images. Remote Sens. 2010, 2, 2665-2679. [CrossRef]

70. Eigirdas, M.; Augustaitis, A.; Mozgeris, G. 2013 Predicting tree crown defoliation using color-infrared orthophoto maps. iForest 2013, 6, 23-29. [CrossRef]

71. Zarco-Tejada, P.J.; Miller, J.R.; Mohammed, G.H.; Noland, T.L.; Sampson, P.H. Vegetation Stress Detection through Chlorophyll $\mathrm{a}+\mathrm{b}$ Estimation and Fluorescence Effects on Hyperspectral Imagery. J. Environ. Qual. 2002, 31, 1433-1441. [CrossRef] [PubMed]

72. Moreno, J.; Asner, G.P.; Bach, H.; Belenguer, T.; Bell, A.; Buschmann, C.; Calera, A.; Calpe, J.; Campbell, P.; Cecchi, G.; et al. Fluorescence explorer (FLEX): An optimised payload to map vegetation photosynthesis from space. In Proceedings of the AIAA 57th International Astronautical Congress, Valencia, Spain, 2-6 October 2006; Volume 3, pp. 2065-2074.

73. Huete, R.H. Vegetation Indices, Remote Sensing and Forest Monitoring. Geogr. Compass 2012, 6, 513-532. [CrossRef]

74. Serbin, S.P.; Dillaway, D.N.; Kruger, E.L.; Towsend, P.A. Leaf optical properties reflect variation in photosynthetic metabolism and its sensitivity to temperature. J. Exp. Bot. 2012, 63, 489-502. [CrossRef] [PubMed]

75. Parazoo, N.C.; Bowman, K.; Fisher, J.B.; Frankenberg, C.; Jones, D.B.A.; Cescatti, A.; Pérez-Priego, Ó.; Wohlfahrt, G.; Montagnani, L. Terrestrial gross primary production inferred from satellite fluorescence and vegetation models. Glob. Chang. Biol. 2014, 20, 3103-3121. [CrossRef] [PubMed]

76. Lausch, A.; Erasmi, S.; King, D.J.; Magdon, P.; Heurich, M. Understanding Forest Health with Remote Sensing-Part I-A Review of Spectral Traits, Processes and Remote-Sensing Characteristics. Remote Sens. 2016, 8, 1029. [CrossRef]

77. Lausch, A.; Erasmi, S.; King, D.J.; Magdon, P.; Heurich, M. Understanding Forest Health with Remote Sensing-Part II-A Review of Approaches and Data Models. Remote Sens. 2017, 9, 129. [CrossRef]

78. Pause, M.; Schweitzer, C.; Rosenthal, M.; Keuck, V.; Bumberger, J.; Dietrich, P.; Heurich, M.; Jung, A.; Lausch, A. In Situ/Remote Sensing Integration to Assess Forest Health—A Review. Remote Sens. 2016, 8, 471. [CrossRef]

79. Cendrero-Mateo, M.P.; Moran, M.S.; Papuga, S.A.; Thorp, K.R.; Alonso, L.; Moreno, J.; Ponce-Campos, G.; Rascher, U.; Wang, G. Plant chlorophyll fluorescence: Active and passive measurements at canopy and leaf scales with different nitrogen treatments. J. Exp. Bot. 2016, 67, 275-286. [CrossRef] [PubMed] 
80. Jacob, D.; Petersen, J.; Eggert, B.; Alias, A.; Christensen, O.B.; Bouwer, L.M.; Braun, A.; Colette, A.; Deque, M.; Georgievski, G.; et al. EURO-CORDEX: New high-resolution climate change projections for European impact research. Reg. Environ. Chang. 2014, 14, 563-578. [CrossRef]

81. Hanewinkel, M.; Cullmann, D.A.; Schelhaas, M.-J.; Nabuurs, G.-J.; Zimmermann, N.E. Climate change may cause severe loss in the economic value of European forest land. Nat. Clim. Chang. 2013, 3, $203-207$. [CrossRef]

82. Pretzsch, H.; Biber, P.; Schütze, G.; Bielak, K. Changes of forest stand dynamics in Europe. Facts from long-term observational plots and their relevance for forest ecology and management. For. Ecol. Manag. 2014, 316, 65-77. [CrossRef]

83. Pretzsch, H.; Biber, P.; Schütze, G.; Uhl, E.; Rötzer, T. Forest stand growth dynamics in Central Europe have accelerated since 1870. Nat. Commun. 2014, 5, 4967. [CrossRef] [PubMed]

84. Rydsaa, J.H.; Stordal, F.; Tallaksen, L. Sensitivity of the regional European boreal climate to changes in surface properties resulting from structural vegetation perturbations. Biogeosciences 2015, 12, 3071-3087. [CrossRef]

85. Marini, L.; Økland, B.; Jönsson, A.M.; Bentz, B.; Carroll, A.; Forster, B.; Grégoire, J.C.; Hurling, R.; Nageleisen, L.M.; Netherer, S.; et al. Climate drivers of bark beetle outbreak dynamics in Norway spruce forests. Ecography 2017, 40, 1-10. [CrossRef]

86. Oleksyn, J.; Tjoelker, M.G.; Reich, P.B. Adaptation to changing environment in Scots pine populations across a latitudinal gradient. Silva Fenn. 1998, 32, 129-140. [CrossRef]

87. Salvatori, E.; Fusaro, L.; Manes, F. Chlorophyll fluorescence for phenotyping drought-stressed trees in a mixed deciduous forest. Ann. Bot. 2016, 6, 81-91.

88. Baeten, L.; Verheyen, K.; Wirth, C.; Bruelheide, H.; Bussotti, F.; Finér, L.; Jaroszewicz, B.; Selvi, F.; Valladares, F.; Allan, E.; et al. A novel comparative research platform designed to determine the functional significance of tree species diversity in European forests. Perspect. Plant Ecol. Evol. Syst. 2013, 15, 281-291. [CrossRef]

89. Thuiller, W.; Albert, C.; Araújo, M.B.; Berry, P.M.; Cabeza, M.; Guisan, A.; Hickler, T.; Midgley, G.F.; Paterson, J.; Schurr, F.M.; et al. Predicting global change impacts on plant species' distributions: Future challenges. Perspect. Plant Ecol. Evol. Syst. 2008, 9, 137-152. [CrossRef]

90. Hickler, T.; Vohland, K.; Feehan, J.; Miller, P.A.; Smith, B.; Costa, L.; Giesecke, T.; Fronzek, S.; Carter, T.R.; Cramer, W.; et al. Projecting the future distribution of European potential natural vegetation zones with a generalized, tree species-based dynamic vegetation model. Glob. Ecol. Biogeogr. 2012, 21, 50-63. [CrossRef]

91. Aravanopoulos, F.; Tollefsrud, M.M.; Graudal, L.; Koskela, J.; Kätzel, R.; Soto de Viana, A.; Nagy, L.; Pilipović, A.; Stoyanov, P.Z.; Bozič, G.; et al. Genetic Monitoring Methods for Genetic Conservation Units of Forest Trees in Europe. 2015. Available online: http:/ / www.euforgen.org/ (accessed 10 March 2017). 